\title{
Risk Factors of Hepatitis C in the Suez Canal Region, Egypt
}

\author{
Hesham El-Sayed ${ }^{1}$, Sohair Mehanna ${ }^{2}$, Adel Hassan ${ }^{3}$, Mahmoud Sheded ${ }^{4}$, \\ Shaimaa Sahmoud ${ }^{1}$, Samar Elfiky ${ }^{1}$, Zeinab Khadr ${ }^{2}$ \\ ${ }^{1}$ Department of Pediatrics, Faculty of Medicine, Suez Canal University, Egypt. \\ ${ }^{2}$ Social Research Center, American University in Cairo, Egypt. \\ ${ }^{3}$ Department of Infectious Diseases, Faculty of Medicine, Suez Canal University, Egypt. \\ ${ }^{4}$ Department of Endemic and Infectious Diseases, Faculty of Medicine, Suez University, Egypt.
}

Corresponding Author Adel Hassan

Mobile: +2

01005665450

\section{E mail:}

ahadel2001@yahoo.co $m$

Key words: risk factors, $\mathrm{HCV}$, Suez Canal, Egypt
Background and study aim: Egypt has very high prevalence of Hepatitis $C$ virus (HCV) infection Aim: To identify possible risk factors of $\mathrm{HCV}$ in Suez Canal region of Egypt.

Materials and Methods: HCV positive individuals in 5 different hospitals and control blood donors were subjected to anti HCV tests and interview questionnaire to identify risk factors.

Results: A total of 1176 subjects were studied for $\mathrm{HCV}$, of which 539 were HCV-positive and637 HCV-negative donors. Subjects who achieved less than university education, unemployed or gaining less than 600 Egyptian pounds monthly had an increased risk of $\mathrm{HCV}$ $(\mathrm{OR}=4.18, \mathrm{CI} 3.28-5.34, \mathrm{p} 0.000),(\mathrm{OR}=$ 3.26, CI 2.55-4.16, p 0.000), and $(\mathrm{OR}=$ 3.32, CI 2.59-4.26, p 0.000). Informal male circumcision doubled the risk of $\mathrm{HCV}(\mathrm{OR}=2.08$, CI 1.53-2.83, p 0.000).
Shaving at a barber and sharing razors increased $\mathrm{HCV}$ risk 2 times, while sharing tooth brushes increased it 7 times (OR = 7.23, CI 2.74-18.79, p 0.000). HCV risk increased after endoscopy $(\mathrm{OR}=3.62$, CI2.02-6.52, p 0.000), blood transfusion (OR 3.47, CI 2.18-5.54, p 0.000), and injection treatment $(\mathrm{OR}=1.41$, CI 1.02$1.95, \mathrm{p}$ 0.040). Any delivery and dental care in governmental clinic were independent risk factors (OR 2.57, CI 1.25-5.30, 0.011), (OR 1.46, CI 1.08-1.97, p 0.014). Schistosomiasis parenteral treatment doubled the $\mathrm{HCV}$ risk $(\mathrm{OR}=2.09$, CI 1.35-3.23, p 0.001) and chronic kidney disease patients were more at risk $(\mathrm{OR}=$ 2.95, CI 1.40-6.24, p 0.005).

Conclusion: Infection control in medical practice and behavioral modifications in this region is essential to prevent $\mathrm{HCV}$ transmission.

\section{INTRODUCTION}

Infection by hepatitis $\mathrm{C}$ virus (HCV) is now recognized as a major world public health problem. The global prevalence of anti HCV increased from $2.3 \%$ to $2.8 \%$ between 1990 and 2005 [1]. While regions like central and east Asia and North Africa/middle East are estimated to have high prevalence (>3.5\%), areas like South Asia, Latin America and Australia have moderate prevalence (1.5-3.5\%), whereas Asia Pacific, Tropical Latin America, and North America have low prevalence $(<1.5 \%)$ [1]. Infection with HCV is a major health problem in Egypt [2]. The Egyptian Demographic Health Survey (DHS) 2015 estimated that overall $6.3 \%$ had ever been infected with hepatitis $\mathrm{C}$ virus while only $4.4 \%$ had active hepatitis $\mathrm{C}$. These numbers were lower than the $14.7 \%$ overall prevalence of positive patients for antibody to HCV found in the 2009 DHS survey [2]. Certain governorates in Egypt are identified as high prevalent areas like the interface between the governorate of Beni Suef and Minya, Faiyum, Dakahlia, Kafr el Sheikh, Monufia, and Minya [3]. Apart from the usual modes of transmission, such as intravenous drug usage, the main risk factors for transmission in Egypt historically have included the parenteral antischistosomal therapy (PAT), shared or reused needles, poorly sterilized surgical or dental equipment, and blood transfusions [4]. Contrary to this historical view, in a cluster-based analyses a rather weak and statistically 
not significant association between HCV prevalence and previous PAT was found. In Suez, despite there was no reported PAT exposures nor a history of PAT campaigns, HCV prevalence was nearly as high as the national HCV prevalence [3]. Few data are available about the risk factors associated with HCV infection in the Suez Canal region in Egypt. There is need for proper program to control spread of the disease and to alleviate the suffering of the people. It is essential to understand the dynamics of its transmission that can be utilized to guide screening procedures as well as provide insight into the control and prevention of the disease. Furthermore, there is need to identify the risk factors that are responsible for the continued endemic transmission of HCV in Egypt. This work studied the behavioral aspects and life style of HCV patients in the Suez Canal region in Egypt compared to controls from the same region.It also describes the demographic characteristics of $\mathrm{HCV}$ infected patients in the Suez Canal region. This study was conducted during the years 20142017.

\section{MATERIALS AND METHODS}

A case-control study was conducted among HCV positive individuals referred to the Suez Canal University Hospital in Ismailia governorate, the Communicable Diseases Research and Training Center in Suez governorate, and three Fever Hospitals in Port-Said, Ismailia, and Suez Governorates from October 2014 to September 2017. On the basis of a specially designed protocol, standard commercially available tests and physical examinations were performed. The analysis included data of medical history, physical examination and serological evaluation. All subjects were evaluated using a face-to-face questionnaire about demographic and socioeconomic aspects, parenteral exposure to blood or blood products, social and sexual behavior, occupational exposure, intravenous drug use, tattooing, acupuncture, surgery, previous hospitalization and parenteral administration of drugs, personal history of jaundice or hepatitis or history of these diseases in the cases' and controls' families. The control group consisted of blood donors referred to the Regional Blood Transfusion clinics. None of the control group subjects were HBsAg positive, HIV-positive or have any signs or symptoms of hepatitis. Antibodies to $\mathrm{HCV}$ were detected employing a commercially available second-generation enzyme immunoassay (Organon/ Teknica UB/HCV EIA). Positive serum specimens were retested using a second-generation recombinant immunoblotassay (RIBA-2) and a polymerase chain reaction for HCV RNA(Abbott Lab., Abbott Park, IL, USA).

Reported risk factors among infected subjects ("HCV- positive") were compared to those of subjects never exposed ("HCV-negative") to HCV.

\section{Statistical analyses:}

Collected data were coded, analyzed and computed, using the Statistical Package for Social Sciences (SPSS) version 10 (SPSS Inc., Chicago, IL, USA). Simple statistics such as frequency, and standard deviation were used. Chi-square and Student's t-tests were used for comparison.

We conducted age adjusted multivariate logistic regression analysis to identify risk factors associated with HCV infection.

\section{RESULTS}

A total of 1176 subjects were studied for $\mathrm{HCV}$, of which 539 were $\mathrm{HCV}$-positive and 637were HCV-negative donors comprised the control group. $1.6 \%$ of the patients had both HCV and HBV infections. Mean age of the patients was 48.3 (SD 11.00) years. Of the 539 patients, 276 $(52.21 \%)$ were males, and $71.79 \%$ were from urban areas. Of the studied patients and their families, $6.13 \%$ of the spouses and $0.56 \%$ of their children had HCV. Demographic factors significantly affected the risk of $\mathrm{HCV}$ transmission as we found that patients who achieved less than university education, unemployed, or gaining less than 600 Egyptian pound monthly income had an increased risk of $\mathrm{HCV}(\mathrm{OR}=4.18$, CI 3.28-5.34, p 0.000), (OR= 3.26, CI 2.55-4.16, p 0.000), and ( $\mathrm{OR}=3.32$, CI 2.59-4.26, p 0.000). People who ever travelled abroad was almost 2 times more prone to infection than those who didn't $(\mathrm{OR}=1.64$, CI 1.26-2.14, $\mathrm{p}$ 0.000). Marriage was found one of the risk factors of HCV transmission among our study group as we found that subjects who ever married were about 5 times more likely to have $\mathrm{HCV}(\mathrm{OR}=5.45$, CI 3.64-8.17, p 0.000). Male circumcision by informal health providers doubled the risk of $\mathrm{HCV}(\mathrm{OR}=2.08$, CI 1.53$2.83, \mathrm{p}$ 0.000). Shaving at a barber, sharing razors and tooth brushes were also risky $(\mathrm{OR}=$ 1.81, CI 1.27-2.58, p 0.001), $(\mathrm{OR}=2.43$, CI $1.54-3.84, \mathrm{p} 0.001)$, and $(\mathrm{OR}=7.23$, CI 2.74$18.79, \mathrm{p} 0.000)$. Ear piercing increased the risk of 
$\mathrm{HCV}$ transmission $(\mathrm{OR}=3.11$, CI 2.23-3.35) while other practices like Smoking hubblebubble and tattoo formation were of insignificant risk $(\mathrm{p}=0.440$, and 0.184$)$. Hospital admissions and major surgical procedures weren't identified as independent risks of HCV ( $\mathrm{p} 0.861, \mathrm{p} 0.086$ ), but risk increased after endoscopy $(\mathrm{OR}=3.62, \mathrm{CI}$ 2.02-6.52, p 0.000), blood transfusion (OR 3.47, CI 2.18-5.54, p 0.000), and injection treatment inside hospitals $(\mathrm{OR}=1.41, \mathrm{CI} 1.02-1.95, \mathrm{p}$ 0.040 ). Any delivery was a risk factor (OR 2.57, CI 1.25-5.30, 0.011), Caesarean section (CS) delivery or episiotomy almost doubled the risk (OR 2.50, CI 1.42-4.39, p 0.001), and home delivery was also identified as a risk factor (OR 0.36 , CI 0.20-0.65, p 0.001). Dental care in governmental clinic only was of a significant risk (OR 1.46, CI 1.08-1.97, p 0.014). HCV infection was also more common among persons having history of schistosomiasis infection $(\mathrm{OR}=1.74$, CI 1.29-2.35, p 0.000), especially among those received injections for treatment $(\mathrm{OR}=2.09$, CI 1.35-3.23, p 0.001). An increased risk of infection was found in chronic kidney disease patients (OR=2.95, CI 1.40-6.24, p 0.005) but not in diabetics receiving frequent injection $(\mathrm{p}$ 0.319 ).

Table (1): Demographic characteristics of the study group

\begin{tabular}{|c|c|c|c|c|}
\hline & \multicolumn{2}{|c|}{$\begin{array}{l}\text { HCV positive } \\
\text { Cases }(n=539)\end{array}$} & \multicolumn{2}{|c|}{$\begin{array}{c}\text { HCV negative } \\
\text { Controls }(n=637)\end{array}$} \\
\hline & $\mathbf{N}$ & $\%$ & $\mathbf{N}$ & $\%$ \\
\hline $\begin{array}{c}\text { Age (years) } \\
\quad<30 \\
\quad>30\end{array}$ & $\begin{array}{c}35 \\
504\end{array}$ & $\begin{array}{c}6.49 \\
93.51\end{array}$ & $\begin{array}{l}244 \\
393\end{array}$ & $\begin{array}{l}38.30 \\
61.70\end{array}$ \\
\hline Mean age years \pm SD & \multicolumn{2}{|c|}{$48.3 \pm 11$} & \multicolumn{2}{|c|}{$34.28 \pm 10.9$} \\
\hline $\begin{array}{l}\text { Gender } \\
\text { Male }\end{array}$ & 276 & 51.21 & 486 & 76.29 \\
\hline $\begin{array}{l}\text { Marital status } \\
\text { Never married } \\
\text { Previously married } \\
\text { Currently married }\end{array}$ & $\begin{array}{c}31 \\
68 \\
440\end{array}$ & $\begin{array}{l}5.75 \\
12.62 \\
81.63\end{array}$ & $\begin{array}{c}159 \\
27 \\
451\end{array}$ & $\begin{array}{c}24.96 \\
4.24 \\
70.80\end{array}$ \\
\hline $\begin{array}{l}\text { Educational attainment } \\
\text { No education } \\
\text { Read and write } \\
\text { Less than University } \\
\text { University and more }\end{array}$ & $\begin{array}{c}203 \\
147 \\
156 \\
33\end{array}$ & $\begin{array}{c}37.66 \\
27.27 \\
28.94 \\
6.13\end{array}$ & $\begin{array}{c}97 \\
97 \\
318 \\
125\end{array}$ & $\begin{array}{l}15.23 \\
15.23 \\
49.92 \\
19.62\end{array}$ \\
\hline $\begin{array}{l}\text { Work status } \\
\text { Not working } \\
\text { Workman } \\
\text { Employee }\end{array}$ & $\begin{array}{l}283 \\
150 \\
106\end{array}$ & $\begin{array}{l}52.50 \\
27.83 \\
19.67\end{array}$ & $\begin{array}{l}161 \\
254 \\
222\end{array}$ & $\begin{array}{l}25.27 \\
39.87 \\
34.86\end{array}$ \\
\hline $\begin{array}{l}\text { Monthly income } \\
\quad<200 \\
200-400 \\
400- \\
600- \\
800- \\
+1000\end{array}$ & $\begin{array}{c}86 \\
97 \\
92 \\
107 \\
115 \\
42\end{array}$ & $\begin{array}{c}15.96 \\
17.99 \\
17.07 \\
19.85 \\
21.34 \\
7.79\end{array}$ & $\begin{array}{c}24 \\
56 \\
76 \\
107 \\
175 \\
199\end{array}$ & $\begin{array}{c}3.77 \\
8.79 \\
11.93 \\
16.79 \\
27.47 \\
31.25\end{array}$ \\
\hline $\begin{array}{l}\text { Place of residence } \\
\text { Urban } \\
\text { Rural }\end{array}$ & $\begin{array}{l}387 \\
152\end{array}$ & $\begin{array}{l}71.79 \\
28.21\end{array}$ & $\begin{array}{l}350 \\
287\end{array}$ & $\begin{array}{l}54.95 \\
45.05\end{array}$ \\
\hline Previously travelled abroad & 162 & 30.06 & 132 & 20.72 \\
\hline
\end{tabular}


Table (2): Demographic and behavioral risk factors associated with HCV transmission

\begin{tabular}{|l|c|c|c|c|c|c|c|}
\hline \multirow{2}{*}{ Variable } & \multicolumn{2}{|c|}{ Cases $=539$} & \multicolumn{2}{c|}{ Controls=637 } & \multirow{2}{*}{ OR } & \multirow{2}{*}{ 95\% CI } & \multirow{2}{*}{ P value } \\
\cline { 2 - 5 } & $\mathbf{N}$ & $\mathbf{\%}$ & $\mathbf{N}$ & $\mathbf{\%}$ & & & \\
\hline Less than university education & 348 & 64.56 & 194 & 30.46 & 4.18 & $3.28-5.34$ & $0.000^{*}$ \\
\hline Unemployment & 283 & 52.50 & 161 & 25.27 & 3.26 & $2.55-4.16$ & $0.000^{*}$ \\
\hline $\begin{array}{l}\text { Low economic status }(<600 \\
\text { LE/mo.) }\end{array}$ & 270 & 50.09 & 148 & 23.23 & 3.32 & $2.59-4.26$ & $0.000^{*}$ \\
\hline Ever travelled abroad & 162 & 30.06 & 131 & 20.57 & 1.64 & $1.26-2.14$ & $0.000^{*}$ \\
\hline Ever married & 508 & 94.25 & 478 & 75.04 & 5.45 & $3.64-8.17$ & $0.000^{*}$ \\
\hline $\begin{array}{l}\text { Males circumcised by informal } \\
\text { health care provider }\end{array}$ & 222 & 41.19 & 121 & 19.00 & 2.08 & $1.53-2.83$ & $0.000^{*}$ \\
\hline Tattoo & 25 & 1.69 & 17 & 2.67 & 0.78 & 3.67 & 0.184 \\
\hline Shaving at barber & 453 & 84.04 & 494 & 77.55 & 1.81 & $1.27-2.58$ & $0.001^{*}$ \\
\hline Sharing razors & 84 & 15.58 & 46 & 7.22 & 2.43 & $1.54-3.84$ & $0.001^{*}$ \\
\hline Sharing tooth brush & 37 & 6.8 & 6 & 0.94 & 7.23 & $2.74-18.79$ & $0.000^{*}$ \\
\hline Ear piercing & 207 & 39.13 & 82 & 12.87 & 3.11 & $2.23-3.35$ & $0.000^{*}$ \\
\hline Smoking hubble-bubble & 82 & 15.21 & 94 & 14.76 & 0.86 & $0.59-1.26$ & 0.440 \\
\hline
\end{tabular}

OR:Odds Ratio (Age-adjusted OR based on multivariate logistic-regression model)

CI:Confidence Interval, * statistically significant.

Table (3): Health care risk factors associated with HCV infection

\begin{tabular}{|c|c|c|c|c|c|c|c|}
\hline \multirow{2}{*}{ Variable } & \multicolumn{2}{|c|}{ Cases $=539$} & \multicolumn{2}{|c|}{ Controls $=637$} & \multirow{2}{*}{ OR } & \multirow{2}{*}{$95 \% \mathrm{CI}$} & \multirow{2}{*}{$\begin{array}{c}\mathbf{P} \\
\text { value }\end{array}$} \\
\hline & $\mathbf{N}$ & $\%$ & $\mathbf{N}$ & $\%$ & & & \\
\hline $\begin{array}{l}\text { Hospital and clinic exposures } \\
\text { i. Admissions } \\
\text { ii. Injections in the hospital } \\
\text { iii. Major surgical procedures } \\
\text { iv. Endoscopy } \\
\text { v. Blood transfusion } \\
\end{array}$ & $\begin{array}{c}272 \\
167 \\
285 \\
92 \\
131 \\
\end{array}$ & $\begin{array}{l}50.46 \\
30.98 \\
52.88 \\
17.07 \\
24.30 \\
\end{array}$ & $\begin{array}{c}239 \\
112 \\
280 \\
17 \\
30 \\
\end{array}$ & $\begin{array}{r}37.52 \\
17.58 \\
43.96 \\
2.67 \\
4.71 \\
\end{array}$ & $\begin{array}{l}1.26 \\
1.41 \\
1.11 \\
3.62 \\
3.47 \\
\end{array}$ & $\begin{array}{l}0.77-1.36 \\
1.02-1.95 \\
0.84-1.46 \\
2.01-6.52 \\
2.18-5.54 \\
\end{array}$ & $\begin{array}{c}0.861 \\
0.040^{*} \\
0.476 \\
0.000^{*} \\
0.000^{*}\end{array}$ \\
\hline $\begin{array}{l}\text { Obstetric exposures (women) } \\
\text { 1. Any delivery } \\
\text { 2. Surgical delivery (CS or } \\
\text { episiotomy) } \\
\text { 3. Home delivery }\end{array}$ & $\begin{array}{l}239 \\
110 \\
74\end{array}$ & $\begin{array}{l}92.64 \\
44.00 \\
\\
30.71\end{array}$ & $\begin{array}{l}98 \\
30 \\
36\end{array}$ & $\begin{array}{l}78.40 \\
31.91 \\
\\
37.89\end{array}$ & $\begin{array}{l}2.57 \\
2.50 \\
\\
0.36\end{array}$ & $\begin{array}{l}1.25-5.30 \\
1.42-4.39 \\
0.20-0.65\end{array}$ & $\begin{array}{l}0.011^{*} \\
0.001 * \\
0.001 *\end{array}$ \\
\hline $\begin{array}{l}\text { Dental treatment } \\
\text { A. Any treatment } \\
\text { B. Private clinic } \\
\text { C. Governmental clinic (e.g., } \\
\quad \text { MOH) }\end{array}$ & $\begin{array}{l}476 \\
251 \\
227\end{array}$ & $\begin{array}{l}88.64 \\
46.57 \\
42.12\end{array}$ & $\begin{array}{l}453 \\
310 \\
143\end{array}$ & $\begin{array}{l}71.34 \\
48.67 \\
22.45\end{array}$ & $\begin{array}{l}1.43 \\
0.86 \\
1.46\end{array}$ & $\begin{array}{l}0.98-2.08 \\
0.66-1.14 \\
1.08-1.97\end{array}$ & $\begin{array}{c}0.064 \\
0.303 \\
0.014 *\end{array}$ \\
\hline $\begin{array}{l}\text { Chronic medical diseases } \\
\text { a. History of schistosomiasis } \\
\text { b. Schistosomiasis injections } \\
\text { treatment } \\
\text { c. Diabetics receiving frequent } \\
\text { injection } \\
\text { d. Chronic kidney disease }\end{array}$ & $\begin{array}{l}241 \\
146 \\
49 \\
48\end{array}$ & $\begin{array}{r}44.71 \\
27.09 \\
9.09 \\
8.91\end{array}$ & $\begin{array}{c}134 \\
34 \\
12 \\
11\end{array}$ & $\begin{array}{c}21.04 \\
5.34 \\
1.88 \\
1.73\end{array}$ & $\begin{array}{l}1.74 \\
2.09\end{array}$ & $\begin{array}{l}1.29-2.35 \\
1.35-3.23 \\
0.71-2.86 \\
1.40-6.24\end{array}$ & $\begin{array}{c}0.000^{*} \\
0.001^{*} \\
0.319 \\
0.005^{*}\end{array}$ \\
\hline
\end{tabular}

OR:Odds Ratio(Age-adjusted OR based on multivariate logistic-regression model)

CI:Confidence Interval, * statistically significant. 
Hepatitis $\mathrm{C}$ infection is a raising problem and its long term complications like cirrhosis and hepatocellular carcinoma is considered a particular health burden [5]. Route of transmission varies between developed and developing countries. In developed countries after the World War II and up until 1980s parenteral exposure to contaminated blood and blood products and the use of injectable drugs were the most common source of infection [6]. The routine screening of HCV in the donated blood eliminated this source of infection in most of the developed countries leaving the illicit use of injectable drugs the most common rout of transmission [7]. In the developing countries, the nosocomial transmission of $\mathrm{HCV}$ is the main source of new HCV infection due to the reuse or under sterilization of medical equipment $[8,9,10]$. In our study we found the prevalence of Co infection of both hepatitis B and $\mathrm{C}$ virus was $1.6 \%$. This might be explained by the fact that both infections share common routes of infection. Nevertheless, this prevalence was lower than what an Italian study reported of almost $7 \%$ of hepatitis B positive patients with anti $\mathrm{HCV}$ as well [11]. We found that anti $\mathrm{HCV}$ were more common in urban than rural areas in the Suez Canal region (71.79\%, and $28.21 \%$ respectively), which was the contrary of what the latest DHS survey reported of whole Egypt [2]. Of our studied patients and their families, 6.13\% of the spouses and $0.56 \%$ of their children had HCV. Although some studies found a higher HCV sero-prevalence of family member $[\mathbf{1 2 , 1 3}$, others found only $1.33 \%$ [14]. Similar to our study among the household contacts of HCV seropositive index cases, spouses were found to be the most affected but still this can't be explained by the sexual transmission only as partners tools sharing is a risky behavior by itself [15]. Illiteracy, unemployment, and low economic status increased the risk of HCV by 3 to 4 folds. In the same way, we previously identified socioeconomic status and knowledge as risk factors of hepatitis in Ismailia as one of the governorates in Suez Canal area [16]. Others also found that $\mathrm{HCV}$ in Egypt were common among low educated patients and that mothers of low education tend to share personal tools [17]. Sharing tools was repeatedly identified as a risk factor of HCV transmission [10,17]. It increased the risk in our group up to 7 times. In our study, shaving at a barber, sharing razors and tooth brushes were significant predictors of $\mathrm{HCV}$ infection. In two previous studies conducted in Egypt one study identified barber shaving as a risk factor [17] while the other one didn't [10] although the former one was more recent. Like many other studies $[\mathbf{1 0 , 1 7 , 1 9 ]}$ we found that circumcision by informal health care provider was a predictor of $\mathrm{HCV}$ infection. Our results revealed that major surgical procedures didn't significantly increase the risk of $\mathrm{HCV}$, but risk increased after endoscopy, blood transfusion, and injection treatment inside hospitals. Blood transfusion is identified as a current risk factor of $\mathrm{HCV}$ transmission in the developing countries like Egypt [20]. Interestingly, when Upper Egypt and The Nile Delta was compared, unlike Upper Egypt blood transfusion was not a risk of $\mathrm{HCV}$ infection in the Nile Delta what might be explained by the younger age in the latter as the donor anti HCV screening was started in Egypt in 1991 [20]. Several invasive procedures were associated with acquiring new HCV infections as they were identified as the most common risk factor of $\mathrm{HCV}$ transmission even in developed countries [21-23]. In Egypt the specific increase in the prevalence of new HCV infection after endoscopy procedures might be explained by the high number of patients with chronic hepatitis B and schistosomiasis requiring endoscopy what could be minimized with following the recommended sterilization techniques [24-26]. Our finding went with what repeatedly found by others regarding the parenteral anti schistosomiasis therapy risk of causing HCV [27-32]; as we found that history of schistosomiasis increased the risk by 2.5 folds, and those who reported a history of parenteral therapy for schistosomiasis were almost three times as likely to have antiHCV than those who did not. Obstetric exposure was a predictor of $\mathrm{HCV}$ infection in our study group but was not a significant factor in other studies $[\mathbf{1 0 , 1 7 ]}$. In Suez Canal area, dental care in governmental centers only was still a significant risk of HCV. In Alexandria any dental care was identified risky [19] while dental care in Upper Egypt and Sharkia governorates wasn't a risk factor of HCV transmission [10,17]. Health care exposure was also identified as the most important risk factor of the ongoing $\mathrm{HCV}$ transmission; probably due to the lack of decontamination techniques before the minor procedures [33] what might explain the increased risk of $\mathrm{HCV}$ in patients with chronic kidney disease in our study.

\section{CONCLUSION}


Our data indicate that history of blood transfusion; endoscopy and multiple injections are important risk factors for HCV infection in Egypt. Therefore, focusing on medical practices and infection control in health facilities is essential for HCV transmission prevention. Furthermore, Improvements in certain lifestyle patterns and customs such as sharing razors and tooth brushes especially among $\mathrm{HCV}$ patients and their contacts should be taken in consideration through community education program.

\section{Acknowledgements}

The authors acknowledge the participation and cooperation of the Ministry of Health and population (MOHP) of the Suez Canal region, Egypt. The authors are indebted to all the patients and their families that participated in the study for their kind cooperation.

\section{Ethical approval}

Consent for an interview was taken from each participant, who was assured about the confidentiality of his information. The Ethics Committee of the Ministry of Health and Population approved the study on 12/12/2012 (No: 35-2012/1).

\section{Funding}

The research described in this paper was carried out under the Research Grant Agreement (TC/4/ Health-2010-hep-3271) between Science and Technology Development Fund (STDF) of Egypt and the Faculty of Medicine, Suez Canal University, Egypt.

\section{Conflicts of interest}

There are no conflicts of interest.

\section{REFERENCES}

1. Mohd Hanafiah K, Groeger J, Flaxman AD, Wiersma ST. Global epidemiology of hepatitis C virus infection: New estimates of age-specific antibody to HCV seroprevalence. Hepatology. 2013; 57(4):1333-42.

2. Ministry of Health, Egypt, El-Zanaty and Associates, Egypt and ICF International. (2015). Egypt Health Issues Survey 2015. Cairo, Egypt and Rockville, MD: Ministry of Health and ICF International.

3. Cuadros DF, Branscum AJ, Miller FD, Abu-Raddad LJ. Spatial epidemiology of hepatitis $C$ virus infection in Egypt: analyses and implications. Hepatology. 2014;60(4): 1150-9.
4. Mahmoud YA, Mumtaz GR, Riome S, Miller D, Abu-Raddad LJ. The epidemiology of hepatitis C virus in Egypt: a systematic review and data synthesis. BMC Infectious Diseases. 2013; 13(1):288.

5. Lavanchy D. The global burden of hepatitis C. Liver International. 2009;29(s1):74-81.

6. Donahue JG, Muñoz A, Ness PM, Brown Jr DE, Yawn DH, McAllister Jr et al. The declining risk of post-transfusion hepatitis $\mathrm{C}$ virus infection. New England Journal of Medicine. 1992;327(6):369-73.

7. Wasley A, Alter MJ. Epidemiology of hepatitis C: geographic differences and temporal trends. In Seminars in liver disease 2000 (Vol. 20, No. 01, pp. 0001-0016). Copyright $(2000$ by Thieme Medical Publishers, Inc., 333 Seventh Avenue, New York, NY 10001, USA.

8. Stoszek SK, Abdel-Hamid M, Narooz S, Daly ME, Saleh DA, Mikhail N et al.Prevalence of and risk factors for hepatitis $\mathrm{C}$ in rural pregnant Egyptian women. Transactions of the Royal Society of Tropical Medicine and Hygiene. 2006;100(2):102-7.

9. Hutin YJ, Chen RT. Injection safety: a global challenge. Bulletin of the World Health Organization. 1999;77(10):787.

10. Medhat A, Shehata M, Magder LS, Mikhail N, Abdel-Baki L, Nafeh $M$ et al. Hepatitis c in a community in Upper Egypt: risk factors for infection. The American Journal of Tropical Medicine and Hygiene. 2002;66(5):633-8.

11. Gaeta GB, Stornaiuolo G, Precone DF, Lobello S, Chiaramonte M, Stroffolini $\mathrm{T}$, et al. Epidemiological and clinical burden of chronic hepatitis $\mathrm{B}$ virus/hepatitis $\mathrm{C}$ virus infection. A multicenter Italian study. Journal of Hepatology. 2003; 39(6):1036-41.

12. Pasha O, Luby SP, Khan AJ, Shah SA, McCormick JB, Fisher-Hoch SP. Household members of hepatitis $\mathrm{C}$ virus-infected people in Hafizabad, Pakistan: infection by injections from health care providers. Epidemiology \& Infection. 1999; 123(3):515-8.

13. Akhtar S, Moatter T, Azam SI, Rahbar MH, Adil $S$. Prevalence and risk factors for intrafamilial transmission of hepatitis $\mathrm{C}$ virus in Karachi, Pakistan. Journal of Viral Hepatitis. 2002; 9(4): 309-14.

14. Hajiani E, Masjedizadeh R, Hashemi J, Azmi M, Rajabi T. Hepatitis $C$ virus transmission and its risk factors within families of patients infected with hepatitis $\mathrm{C}$ virus in southern Iran: Khuzestan. World journal of Gastroenterology: WJG. 2006;12(43):7025.

15. Kao JH, Hwang YT, Chen PJ, Yang PM, Lai MY, Wang TH, et al. Transmission of hepatitis C virus between spouses: the important role of 
exposure duration. American Journal of Gastroenterology. 1996 Oct 1;91(10):2087-90.

16. Sahmoud S, Fathey H. Sociodemographic status and knowledge as risk factors of viral hepatitis among children in Ismailia, Egypt. Euro J Pedia 2016; 175(11): 1453-1454.

17. Eassa S, Eissa M, Sharaf SM, Ibrahim MH, Hassanein OM. Prevalence of hepatitis $\mathrm{C}$ virus infection and evaluation of a health education program in el-Ghar village in Zagazig, Egypt. $J$ Egypt Public Health Assoc. 2007; 82(5-6):379404.

18. El-Sadawy M, Ragab H, El-Toukhy H, el-Mor AL, Mangoud AM, Eissa MH et al. Hepatitis C virus infection at Sharkia Governorate, Egypt: seroprevalence and associated risk factors. Journal of the Egyptian Society of Parasitology. 2004; 34(1 Suppl): 367-84.

19. Barakat SH, El-Bashir N. Hepatitis C virus infection among healthy Egyptian children: prevalence and risk factors. Journal of Viral Hepatitis. 2011;18(11):779-84.

20. Habib M, Mohamed MK, Abdel-Aziz F, Magder LS, Abdel-Hamid M, Gamil F et al. Hepatitis C virus infection in a community in the Nile Delta: risk factors for seropositivity. Hepatology. 2001;33(1):248-53.

21. Karmochkine M, Carrat F, Dos Santos O, Cacoub P, Raguin G. A case-control study of risk factors for hepatitis $\mathrm{C}$ infection in patients with unexplained routes of infection. Journal of Viral Hepatitis. 2006;13(11):775-82.

22. Centers for Disease Control and Prevention (CDC. Recommendations for follow-up of health-care workers after occupational exposure to hepatitis C virus. MMWR. Morbidity and mortality weekly report. 1997 Jul 4;46(26):603.

23. Mele A, Spada E, Sagliocca L, Ragni P, Tosti ME, Gallo $G$ et al. Risk of parenterally transmitted hepatitis following exposure to surgery or other invasive procedures: results from the hepatitis surveillance system in Italy. Journal of Hepatology. 2001; 35(2): 284-9.

24. Talaat M, El-Oun S, Kandeel A, Abu-Rabei W, Bodenschatz C, Lohiniva AL, et al.. Overview of injection practices in two governorates in Egypt.
Tropical Medicine \& International Health. 2003;8(3):234-41.

25. Karsenti D, Metman EH, Viguier J, Blanc P, Doumerc S, Dubois F, et al. Transmission by colonoscopy of hepatitis C virus: apropos of a group of 97 patients at presumed risk. Gastroenterologie Clinique et Biologique. 1998; 23(8-9):985-6.

26. Ciancio A, Manzini P, Castagno F, D'Antico S, Reynaudo P, Coucourde L et al. Digestive endoscopy is not a major risk factor for transmitting hepatitis C virus. Annals of Internal Medicine. 2005; 142(11):903-9.

27. Abdel-Aziz F, Habib M, Mohamed MK, AbdelHamid M, Gamil F, Madkour S et al. Hepatitis C virus (HCV) infection in a community in the Nile Delta: Population description and $\mathrm{HCV}$ prevalence. Hepatol 2000; 32: 111-115.

28. Nafeh MA, Medhat A, Shehata M, Mikhail NN, SwifeeY, AbdelHamid $M$ et al. Hepatitis $C$ in a community in Upper Egypt: 1. Cross-sectional survey. Am J Trop Med Hyg 2000;63: 236-241.5.

29. Frank C, Mohamed MK, Strickland GT, Lavanchy D, Arthur RR, Magder LS et al. The role of parenteral antischistosomal therapy in the spread of hepatitis C virus in Egypt. Lancet 2000; 355: 887-891.

30. Darwish MA, Faris R, Darwish N, Shouman A, Gadallah M, El-Sharkawy MS et al. Hepatitis C and cirrhotic liver disease in the Nile Delta of Egypt: a community-based study. Am J Trop Med Hyg 2001;64: 147-153.

31. Quinti I, Renganathan E, El Ghazzawi E, Divizia M, Sawaf G, Awad S et al. Seroprevalence of $\mathrm{HIV}$ and HCV infections in Alexandria, Egypt. Zentralbl Bakteriol 1995;283: 239-244.

32. Angelico M, Renganathan E, Gandin C, Fathy M, Profili MC, Refai W et al. Chronic liver disease in the Alexandria governorate, Egypt: contribution of schistosomiasis and hepatitis virus infections. J Hepatol 1997;26: 236-243.

33. Kandeel AM, Talaat M, Afifi SA, El-Sayed NM, Fadeel MA, Hajjeh RA, et al. Case control study to identify risk factors for acute hepatitis $\mathrm{C}$ virus infection in Egypt. BMC Infectious Diseases. 2012;12(1):294. 